Digitalizacja archiwalnych numerów czasopisma naukowego Analecta Cracoviensia 1-24 (1969-1992)

i ich publikacja w otwartym dostępie - zadanie finansowane w ramach umowy 672/P-DUN/2017 ze środków

Ministra Nauki i Szkolnictwa Wyższego przeznaczonych na działalność upowszechniającą naukę

\title{
NEGOCJATORZY UNII POLSKI Z LITWA I ICH KARIERY
}

W październiku 1384 roku w katedrze wawelskiej arcybiskup gnieźnieński Bodzęta włożył na skronie niespełna jedenastoletniej Jadwigi królewską koronę Piastów ${ }^{1}$. Był to akt o doniosłym znaczeniu. Po ,,wielkim bezkrólewiu" trwającym od roku 1382 Królestwo Polskie miało znowu swego prawowitego monarchę. Nie przeszkadzało, że królem została kobieta, a właściwie wymagające opieki dziecko. Na córkę Ludwika, wielkiego króla Węgier, przystali Polacy już w roku 1374. Zgodę tę okupił ojciec Jadwigi znacznymi ustępstwami na rzecz rycerstwa polskiego ${ }^{2}$. Młody wiek królowej był nawet dla kierowniczych kręgów rycerstwa małopolskiego okolicznością korzystną, mogli bowiem sami faktycznie sprawować rządy w kraju oraz wybrać królowej męża, który najlepiej odpowiadałby polskiej racji stanu.

W marcu 1386 roku w tej samej katedrze, ten sam arcybiskup włożył królewską koronę na głowę wielkiego księcia Litwy Jagiełły, syna sławnego Olgierda. Uroczystości koronacyjne wyprzedził o kilka tygodni ślub dwunastoletniej Andegawenki ze świeżo ochrzczonym trzydziestosześcioletnim Litwinem ${ }^{8}$.

Dwie królewskie koronacje spinają jak klamra trudny okres w dziejach Królestwa Polskiego. Czas między koronacjami wypełniały bowiem gorączkowe przygotowania dyplomatyczne: trudne negocjacje trójstronne oraz poselstwa odwiedzające Wilno, Budę i Kraków. Nie zdawał sobie chyba sprawy arcybiskup gnieźnieński, że koronacjami tymi otworzył nową epokę w dziejach Polski. Nie przypuszczał tė̇ Władysław Jagiełło, że tron polski pozwoli mu się stać twórcą wielkiej dynastii o europejskim znaczeniu. Wielkie wydarzenia wpływające na losy państw wpływają (s. 204).

* Wykaz skrótów, zastosowanych w przypisach, zestawiono na końcu artykułu

1 Data dzienna koronacji nie jest pewna. Kalendarz katedry krakowskiej podaje dzień 15 października (MPH s. n. 5 s. 178). Powtarzają to Spominki gnieznieńskie (MPH s. n. 6 s. 98), a także Rocznik świętokrzyski (MPH 3 s. 81). Dzień 15 października to jednak sobota. Może więc zapiska odnosić się do niedzieli. Taką poprawkę wprowadziła A. Misiąg-Bocheńska (Dwie daty z życia królowej Jadwigi, ,Polonia Sacra" 3: 1949 s. 267-270). Do poprawki tej przychyla się także Zofia Kozłowska-Budkowa (MPH s. n. 5 s. 179 przypis 425).

2 KodWp $3 \mathrm{nr}$ 1709; por. J. Dąbrowski, Dzieje Polski średniowiecznej, t. 2, Kraków 1926, s. 171.

3. Przybyszewski, Wilhelm i Jadwiga, „Analecta Cracoviensia” 7 (1975) s. $131 \mathrm{n}$. 
również na losy jednostek. Jedne $\mathrm{z}$ nich odchodzą $\mathrm{w}$ zapomnienie, inne wpływają na widownię dziejową, by odegrać na niej decydującą nieraz rolę.

Niniejszy artykuł poświęcony jest właśnie ludziom bezpośrednio zaangażowanym w dzieło unii jagiellońskiej. Postaram się odpowiedzieć na pytanie, w jakim stopniu wydarzenia, których byli aktywnymi uczestnikami, wpłynęły na ich dalsze kariery. Zaznaczyć trzeba, że chodzi tu jedynie o dyplomatów prowadzących rokowania, jeżdżących w poselstwach do Wilna i Budy. Oczywiście nie można stracić z pola widzenia ich mocodawców: grupy panów krakowskich, których dziełem było zbliżenie polsko-litewskie. Jest jednak rzeczą bardzo znamienną, że żaden z nich nie zaangażował się bezpośrednio $\mathrm{w}$ rokowania. Trzeba więc odpowiedzieć na pytanie, dlaczego wybrali tych, a nie innych reprezentantów, powierzając im funkcje dyplomatów. Zostali nimi: Krystyn z Ostrowa, Włodko z Charbinowic, Mikołaj kasztelan Zawichostu, a w późniejszym etapie Piotr Szafraniec.

Dyplomatyczne przygotowania, poprzedzające królewską koronację, są bardzo skąpo oświetlone zarówno przez polskie, jak i obce źródła ${ }^{4}$. Taki stan rzeczy można wytłumaczyć w prosty sposób: poufnym charakterem prowadzonych rozmów. Właściwie znany jest jedynie finał rokowań. Przybrał on formę dokumentu Jagiełły wystawionego w Krewie dnia 14 sierpnia $1385 \mathrm{roku}^{5}$. Z punktu widzenia czernastowiecznej praktyki dyplomatycznej akt krewski był protokołem wystawionym przez stronę litewska na zakończenie trójstronnych rozmów w sprawie małżeństwa syna Olgierda. Była to więc umowa przedślubna, trójstronnie wynegocjowana, zaakceptowana przez wielkiego księcia litewskiego. Miała ona jednak charakter wyjątkowy. Posagiem Jadwigi było wszak Królestwo Polskie. Swego rodzaju rewersałem do umowy krewskiej był akt dyplomatów polskich wystawiony $\mathrm{w}$ Wołkowyszkach 11 stycznia 1386 roku ${ }^{6}$. Porównanie dat tych dwóch dokumentów uświadamia, że sam finał rokowań trwał blisko pół roku. Widać prowadzone były one z dużą ostrożnością i rozwagą. Do dokumentu panów polskich z 1386 roku przywiązywałbym dużą wagę. Akt krewski bowiem był jedynie swego rodzaju ofertą Jagiełły wstępnie zaakceptowaną przez dyplomatów polskich i węgierskich. Dokument wystawiony w Wołkowyszkach był akceptacją tej oferty, on też

${ }^{4}$ Por. H. Paszki ew i cz, O genezie $i$ wartości Krewa, Warszawa 1938, s. 201.

5 Akta unii, nr 1.

6 Akta unii, nr 2. 
otwierał synowi Olgierda drogę do korony Piastów. Nie należy jednak zapominać, że bez układów $\mathrm{w}$ Krewie nie byłoby dokumentu z roku 1386 .

Historiografia stawiała w związku z układami krewskimi dwa zasadnicze pytania; która ze stron wystąpiła z inicjatywą rozpoczęcia rozmów oraz kiedy takie rozmowy rozpoczęto ${ }^{7}$. Nie przedstawiając całej, dość kontrowersyjnej sprawy, można zauważyć, że genezy unii szukano w latach 1382-1384 ${ }^{\circ}$. Brano więc praktycznie pod uwagę całe bezkrólewie. Brak źródeł sprawił, że pytania te musiały pozostać po części nierozstrzygnięte. Najwięcej racji miał chyba Anatol Lewicki, pisząc, że takie myśli, jak Unia, ,rodzą się, że tak powiemy, w powietrzu, urzędowe zaś poselstwa niczego nie dowodzą, bo poprzedzają je zawsze poufne negocjacje, których zwykle nie znamy" ".

Wiadomo, że oficjalne poselstwo Jagiełły w sprawie o rękę Jadwigi stanęło w Krakowie 18 stycznia $1385 \mathrm{roku}^{10}$. Wiadomo również, że Jadwiga została w roku 1383 desygnowana przez swoją matkę na tron polski. Oznajmili o tym Polakom posłowie węgierscy przybyli na zjazd sieradzki w lutym 1383 roku; miesiąc później wyrażono formalnie zgodę na kandydaturę Jadwigi pod warunkiem, że przybędzie do Polski ${ }^{11}$. Przedłużająca się nieobecność królowej skłoniła szlachtę do zwołania na dzień 22 września 1384 roku zjazdu elekcyjnego do Sieradza. Widać całkiem poważnie myślano o wyborze króla, nie biorąc pod uwagę Jadwigi. Skoro więc nie był pewny nawet jej przyjazd do Krakowa, to trudno przypuszczać, by od roku 1382 brano w rachubę szukanie dla niej małżonka. Przybycie Andegawenki zasadniczo odmieniło sytuację zważywszy, że wyłączono z góry jej związek z Wilhelmem. Fakt ten, ze względu na spodziewane komplikacje, mógł przyśpieszyć działania. Nie można wykluczyć, że nawet nieco wcześniej myślano o synu Olgierda. Pewne informacje źródłowe wskazują, że właśnie w roku 1384 rozpoczęto wstępne rokowania w sprawie małżeństwa Jadwigi z Jagiełłą. Włodzimierzz Dworzaczek wskazał na obecność Spytka z Melsztyna i Jana z Tarnowa w czasie układów

7 Podsumowanie dyskusji historyków na ten temat daje H. Paszkiewicz (jw., S. 202) oraz S. M. Kuczyński (Rozbiór krytyczny roku 1385 „Dziejów Polski" Jana Długosza, „Studia Źródłoznawcze” 3: 1958 s. 223 przypis 70).

8 Por. S. Zakrze"wski, Wypadki lat 1382-1386 w zwiazku z geneza Unii, [w:] Pamiǫtnik V Zjazdu Historyków Polskich, t. 1, Lwów 1930, s. 345-354; E. M a le czyńska, Książęce lenno mazowieckie, Lwów 1929, s. 38-39.

9 A. L e w icki, Powstanie Swidrygiełty, [w:] Rozprawy Akademii Umiejętności. Wydział Historyczno-Filozoficzny. Seria 2, t. 4 (ogólnego zbioru t. 29), Kraków 1892, s. 418 przypis 8.

10 Kalendarz katedry krakowskiej (MPH s.n. 5 s. 115). Zapiska ta uważana jest za wiarygodną: por. O. $\mathrm{Halecki}$, Przyczynki genealogiczne do dziejów układu krewskiego, „Miesięcznik Heraldyczny” 14 (1935) s. 104-106.

11 Joannis de Czannkow Chronicon Polonorum, MPH 2 s. 732 n. Por. B. Przybyszewski, jw., s. $111-114$. 
Jagiełły z Witoldem w roku $1384^{12}$. Gdyby przyjąć rozumowanie Dworzaczka, to byłby to pierwszy wyraźny ślad kontaktów przywódców Małopolan z wielkim księciem. Drugą wskazówką jest zapiska w najstarszych księgach miasta Krakowa. Informuje ona o ułaskawieniu pewnego oskarżonego na dwa dni przed koronacją Jadwigi ,,ad instanciam magni ducis" ${ }^{18}$. Wskazano trafnie, że w roku 1384 nikt nie mógł przebywać $\mathrm{z}$ takim tytułem w Krakowie $\mathrm{z}$ wyjątkiem poselstwa Jagiełły. Tym wysłannikiem mógł być książę Borys Koriatowicz, książę niżno-nowogrodzki, w roku 1385 również uczestnik uroczystego poselstwa Jagiełły o rękę Jadwigi ${ }^{14}$. Identyfikacja ta, chociaż z konieczności hipotetyczna, ma wszelkie cechy prawdopodobieństwa. Koriatowicz był blisko związany z Węgrami. Borys w roku 1377 był lennikiem Węgier ${ }^{15}$. Właśnie ze względu na stosunki z Węgrami był on odpowiednim posłem dla Jagiełły. Warto jeszcze wspomnieć, że w roku 1384 książę Litwy prowadził równocześnie pertraktacje małżeńskie o rękę córki wielkiego księcia moskiewskiego Dymitra Dońskiego. Zawarto nawet umowę wstępną ${ }^{16}$. Umowa ta nie zamykała, jak widać, możliwości rokowań z Polską i Węgrami. Musiał Borys Koriatowicz użyć całej swej zręczności dyplomatycznej zarówno w Krakowie, jak i w Budzie, by przekonać kompetentne czynniki o korzyściach ze związku Jagiełły z Jadwigą. Przyznać trzeba, że on sam również, jak mało kto, był zainteresowany w doprowadzeniu do szczęśliwego finału owych małżenskich rokowań.

Obecność poselstwa Jagiełły na uroczystościach koronacyjnych Jadwigi ma bardzo istotne znaczenie dla późniejszych rokowań dyplomatycznych. Wysłannicy zetknęli się tutaj z panami krakowskimi, którzy mieli decydujący głos, oraz, co nie było bez znaczenia, z delegacją węgierską towarzyszącą Jadwidze. Na czele tej delegacji stał arcybiskup ostrzyhomski kardynał Dymitr ${ }^{17}$. Mógł on zawieść Elżbiecie Bośniaczce na Węgry wiadomość, że nieskonkretyzowane wcześniej plany małżeńskie zaczynają nabierać realnych kształtów. Musiano w Krakowie podczas koronacji omówić wstępnie wszystkie szczegóły, skoro w trzy miesiące później zja-

12 Por. Scriptores rerum Prussicarum, wyd. T. Hirsch, M. Toppen, E. Strehlke, t. 2, Leipzig 1863, s. 713; W. Dworzaczek, Leliwici Tarnowscy. $Z$ dziejów możnowtadztwa małopolskiego wiek XIV-XV, Warszawa 1971, s. 106.

13 Najstarsze księgi i rachunki miasta Krakowa od roku 1300-1400, wyd. F. Piekosiński, J. Szujski, Kraków 1878, s. 59. Pierwszy zwrócił uwagę na tę zapiskę O. $\mathrm{Halecki}$, Ze studiów nad wielkim bezkrólewiem 1382-1386. "Sprawozdania PAU" 10 (1933) s. 20. Zob. też H. Paszkiewicz, jw., s. 208; "S. M. Kuczyński, jw., s. 220.

14 Por. Akta unii, nr 1; Kalendarz katedry krakowskiej, MPH s.n. 5 s. 115. W sprawie identyfikacji owego księcia Borysa toczyła się swego czasu ożywiona dyskusja, do dzisiaj nie rozstrzygnięta. Zestawienie najważniejszych poglądów daje S. M. Kuczyński (jw. s. 221-223).

15 O. Ha lecki, Przyczynki..., s. 105.

${ }_{16} \mathrm{H}$. P a s z i e w i c z, Jagietto $w$ przededniu unii polsko-litewskiej $w$ oświetleniu nowych źródeł, ,Teki Historyczne" 4 (1950) s. 192.

17 Por. Kalendarz katedry krakowskiej, MPH s.n. 5 s. 172-173, 178. 
wiło się tutaj oficjalne poselstwo od wielkiego księcia Litwy. Wysyłając je, musiał Jagiełło mieć jakieś konkretne gwarancje powodzenia całej misji. W przeciwnym razie nie decydowałby się na zrywanie układów z Dymitrem Dońskim. Do takiego zerwania zaś musiało dojść w momencie wysłania posłów do Krakowa.

Odnosi się wrażenie, że późniejsze negocjacje o rękę Jadwigi, chociaż prowadzone bardzo ostrożnie, miały już formalny charakter. Do Krakowa z pełnomocnictwami Jagiełły przybyła delegacja, na czele której stał młodszy brat Jagiełły Skirgiełło ${ }^{18}$. Obecny był też znany w Krakowie Borys Koriatowicz oraz Olgimunt, książę litewski, i starosta wileński Hanul. W Krakowie Skirgiełło wydał pełnomocnictwa dla Borysa Koriatowicza i Hanula do pertraktacji z królową węgierską Elżbietą Bośniacz$\mathrm{ką}^{19}$. Poselstwo to było konieczne ze względu na wiek Jadwigi, formalnie pozostającej pod opieką matki. Nie bez znaczenia był tu zapewne pewien obyczaj dyplomatyczny, którego starano się przestrzegać, by nie urazić królowej Węgier ${ }^{20}$. Inicjatywa wysłania poselstwa na Węgry wyszła zapewne od samych Małopolan. Tak właśnie przedstawia przebieg wydarzeń Kalendarz katedry krakowskiej. Dla Jagiełły, jak widać, decydujące znaczenie miała zgoda Małopolan. Do poselstwa Borysa Polacy dołączyli trzech swoich przedstawicieli: Włodka - cześnika krakowskiego, Mikołaja - kasztelana zawichojskiego i Krystyna z Ostrowa. Pertraktacje dobiegały końca jednak w Krakowie. Nic więc dziwnego, że tutaj pozostał właściwy kierownik poselstwa Skirgiełło.

Zgoda Elżbiety na małżeństwo córki była formalnością. Niemniej jednak zgodnie z obyczajem dyplomatycznym uważała za stosowne wysłać

18 Akta unii, nr 1. O roli Skirgiełły u boku Władysława Jagiełly wspominał na Zjeździe Historyków Władysław Semkowicz (por. Pamiętnik V Zjazdu Historyków Polskich, t. 2, Lwów 1930, s. 69-71). Wcześniejsze poselstwo Skirgiełły na Węgry w roku 1379 omówił wyczerpująco Stanisław S molk a, (Kiejstut i Jagiełło, [w:] Pamiętnik Akademii Umiejętności, t. 7, Kraków 1889, s. 82 n.).

10 $\mathrm{O}$. Halecki, $O$ genezie $i$ znaczeniu rządów andegaweńskich $w$ Polsce. „Kwartalnik Historyczny” 35 (1924) s. 64 n.

${ }_{20}$ Słusznie jednak wskazała W. M a ci e jewska (Królowa Jadwiga, Kraków 1934 , s. 45), że Polacy mieli prawo rozporządzać ręką Jadwigi. Tak to rozumiał też autor zapiski w Kalendarzu katedry krakowskiej. Na ciekawą drogę sprowadził ostatnio omawiane $\mathrm{l} u$ zagadnienie J. Bardach (Studia $z$ ustroju $i$ prawa Wielkiego Księstwa Litewskiego XIV-XVII w., Warszawa 1970, s. 28 n.). Autor ten wskazał, że mamy tu do czynienia (tzn. w akcie krewskim) z propozycją Jagiełły, by Elżbieta przyjęła go za syna, co byłoby równoznaczne z adopcją. Argumentację tę rozwinął i pogłębił Henryk $€$ ow miań s k i (Studia nad dziejami Wielkiego Księstwa Litewskiego, Poznań 1983, s. 353-354). Autorzy zdają się jednak nie dostrzegać decydującej mimo wszystko roli Małopolan $w$ doprowadzeniu do zawarcia układu. Ośrodkiem, który najwięcej miał tu do powiedzenia był właśnie Kraków, a nie Buda. W historiografii wciąż panuje pogląd wylansowany swego czasu przez Jana Dąbrowskiego o pełnej zgodności interesów Małopolan i dworu węgierskiego. Tymczasem Małopolanie prowadzili w latach 1382-1384 zupełnie samodzielną politykę. Należy mieć na uwadze fakt, że decydujące znaczenie miało wtedy pokolenie, które doszło do władzy i urzędów w ostatnich latach panowania Kazimierza Wielkiego i które nie miało już ,andegaweńskiego kompleksu”. 
do Jagiełły swoich posłów, odpowiadając niejako na jego poselstwo. Wysłannikami Elżbiety został Stefan, prepozyt w Csand, i Władysław kasztelan Potoka. Wysłanie dwuosobowego poselstwa było więc odpowiedzią na dwuosobowe poselstwo Jagiełły. W tym również należy widzieć element ceremoniału dyplomatycznego. Rolę pewnego łącznika między Litwą a Węgrami wzięli na siebie dyplomaci polscy. Z dokumentu krewskiego wynika bowiem, że Elżbieta również na nich rozciągnęła swoje pełnomocnictwa do rozmów z Jagiełłą. Formalnie trzej przedstawiciele Małopolan stawali się więc posłami królowej Węgier. Mimo że pełnomocnictwa otrzymali na Węgrzech, to ważniejsze od tego instrukcje poselskie odebrali w Krakowie. Zgoda Elżbiety, czyniąc zadość obyczajom dyplomatycznym, usuwała ostatnią przeszkodę. Ci sami posłowie polscy podążyli do Krewa, gdzie 14 sierpnia 1385 roku doszło do zawarcia znanej ugody małżeńskiej. Powrót posłów do Krakowa oznaczał zakończenie pierwszego etapu działań dyplomatycznych.

Drugi wyjazd znanej trójki dyplomatów w poselstwie do Jadwigi miał miejsce z początkiem 1386 roku. Tym razem jednak dodano im do towarzystwa podczaszego krakowskiego Piotra Szafrańca. Nie wiadomo niestety, od kogo otrzymali pelnomocnictwa, reprezentowali bowiem nie królowe Jadwige, ale racje ,totius communitatis regni Poloniae" ${ }^{21}$. Do pełnomocnictw poselskich tej delegacji przywiązywałbym dużą wagę. Mogą one bowiem wskazać imiennie tych, którzy reprezentowali interesy Królestwa Polskiego i mogli w jego imieniu wysyłać posłów, a więc faktycznych twórców porozumienia. Posłowie bowiem byli tutaj tylko wyrazicielami ich woli i wykonawcami instrukcji poselskich, działającymi w ramach udzielonych pełnomocnictw. Zgodnie z układami w Wołkowyszkach, wielki książę Litwy miał przybyć do Polski i stanąć na zjeździe generalnym w Lublinie 2 lutego 1386 roku. Przedstawiciele Polski gwarantowali prawo bezpiecznego i swobodnego przejazdu przez terytorium państwa polskiego dla księcia i jego dostojników. Historiografia widzi w tych gwarancjach pewną nieufność i rezerwę ze strony Jagiełły ${ }^{22}$. Nie wydaje się, by taka interpretacja była konieczna. Udzielenie prawa swobodnego przejazdu przez obce terytoria, a dla Jagiełły Królestwo Polskie było formalnie jeszcze obcym terytorium, należało do praktyki dyplomatycznej XIV wieku. Był to salvus conductus, który stosowano powszechnie. Udzielający prawa

21 Akta unii, nr 2. Posłowie oświadczyli, że przybyli ,cum legationibus nobilium procerum maiorum pariter et minorum nec non totius comunitatis regni Poloniae, cum litteris credentialibus, videlicet se renissimi principis Ladislai eadem Dei gracia cum una et eorundem nobilium magnatorum". Warunki układali jednakże w imieniu ,eorundem dominorum cum ipso domino Jagiellone” (tamże). Pełnomocnictwo udzielone przez Władysława Opolczyka, oczywiście w imieniu i z upoważnienia Elżbiety, miało jedynie formalno-prestiżowe znaczenie. $\mathrm{Z}$ tych właśnie względów Elżbieta chciała być obecna do końca prowadzonych rokowań.

${ }^{22} \mathrm{H}$. Paszkiewicz, O genezie..., s. 221. 
swobodnego przejazdu brał pod opiekę monarszą obcą delegację na swoim terytorium. Nie musiał więc Jagiełło żądać prawa swobodnego przejazdu czy o nie zabiegać. Polacy sami, zgodnie z dyplomatycznym obyczajem, zagwarantowali mu to prawo.

Można było natomiast żądać od wielkiego księcia, by pozostawił swych braci w Krakowie w charakterze gwarantów zawartego układu. Mieli oni pozostać tu w załodze aż do momentu wypełnienia przez Jagiełłę zobowiązań wynikających z układu w Krewie. Gwarancje udzielane układom międzypaństwowym, a układy małżeńskie do takich właśnie należały, były praktykowane w czternastowiecznej dyplomacji. Tutaj połączono je z załogą, która w tym wypadku miała charakter takich gwarancji. Książęta litewscy osobnymi dokumentami zobowiązali się do odbycia wspomnianej załogi w Krakowie ${ }^{23}$. Mogli ich z niej warunkowo zwolnić jedynie ci, których „dłużnikami” pozostawali, a więc przedstawiciele Królestwa Polskiego uprawnieni do wysyłania poselstw. W marcu 1386 roku panowie polscy zezwolili Skirgielle opuścić Kraków i udać się na Litwę, mimo odbywania przezeń załogi. Fakt ten poświadczył Władysław Jagiełł, stwierdzając, że stało się to za zgodą Jadwigi oraz panów „universitatis regni Poloniae" ${ }^{24}$. Owymi panami Królestwa Polskiego, którzy wystawili dla Skirgiełły specjalny dokument, byli: arcybiskup gnieźnieński Bodzęta, biskup krakowski Jan, biskup poznański Dobrogost, wojewoda sandomierski Jan, wojewoda krakowski Spytek oraz wojewoda kaliski Sędziwój ${ }^{25}$. Można przyjąc bez ryzyka popełnienia błędu, że ta swego rodzaju „,rada regencyjna" udzieliła posłom pełnomocnictw i instrukcji. Ci panowie Królestwa prowadzili też rokowania w Krakowie ze Skirgiełłą. Oni też byli jeżeli nie pomysłodawcami, to zapewne architektami przyszłej budowli. W ich imieniu udawano się $\mathrm{w}$ poselstwa, ich instrukcji trzymali się posłowie wypełniając swoje misje dyplomatyczne ${ }^{26}$.

\section{II}

Rozpatrzyć teraz wypadnie kariery tych ludzi, którzy wykonywali wielkie polecenia swoich mocodawców. Rola dyplomatów była w tych

\footnotetext{
${ }^{23}$ Istnienie takich osobnych aktów przyjmują S. Kutrzeba i W. Semkowicz (por. Akta unii, nr 3-5).

24 Akta unii nr 12.

25 Tamże nr 10.

${ }^{26}$ Posłowie polscy, udający się wraz z Litwinami na Węgry, zabrali ze sobą jakieś pisma Leliwitów - Tarnowskich. Istniały prawdopodobnie kontakty między nimi, a bawiącym w Polsce w roku 1384 kardynałem Dymitrem. Wyraźnym śladem tych kontaktów jest dokument kardynała nadający odpusty dla kaplicy Panny Marii na zamku tarnowskim. Zostal on wystawiony w Posegawar 7 marca 1383 roku, a więc w miejscu i czasie prowadzenia przez Polaków rokowań z Elżbietą Bośniaczką (zob. ArSang $2 \mathrm{nr}$ 58; O. Hale cki, Dzieje unii jagiellońskiej, t. 1, Kraków 1919, s. 97; W. Dworzaczek, jw., s. 105).
} 
działaniach szczególnie ważna. Mieli bowiem plany i pomysły doprowadzić do konkretnego porozumienia, nadać im formę międzypaństwowych umów.

Ostateczne rokowania $w$ latach $1385-1386$ prowadził ten sam trzyosobowy zespół. W ostatnim tylko poselstwie dołączył do nich Piotr Szafraniec. Prowadzenie rokowań przez tych samych ludzi wynikało z pewnej praktyki dyplomatycznej, która wykształciła się w Polsce jeszcze w czasach Kazimierza Wielkiego. Można wskazać na cały szereg przykładów $\mathrm{z}$ czasów tego monarchy używania tych samych dyplomatów do określonych rokowań. Jeżeli dany zespół rozpoczął rokowania, to w razie, gdy nie nastąpiły jakieś nadzwyczajne okoliczności, zazwyczaj doprowadzał je do finału. Miała taka praktyka swoje dobre strony. Mógł bowiem dyplomata dobrze zaznajomić się ze sprawą, poznawał swych partnerów, miał wyrobione kontakty na obcym dworze. Uczestników poselstw na obce dwory starano się dobierać bardzo umiejętnie. Nie był to w każdym razie dobór przypadkowy, ale starannie obmyślany pod kątem maksymalnych korzyści ${ }^{27}$. Nie zawsze niestety można dokładnie rozpoznać kryteria doboru w tym zakresie. W większości wypadków jest on jednak dobrze czytelny. Nie ulega wątpliwości, że kierownicy polskiej polityki zagranicznej dobierali swych kandydatów bardzo starannie. Ogólne zasady doboru były im zapewne dobrze znane. Pozytywne świadectwo w tym względzie wystawia im powierzanie rokowań tej samej grupie ludzi. Kryteria doboru tych ludzi można rozpoznać tylko poprzez ich kariery i powiązania sprzed roku 1385. Musieli posiadać jakieś szczególne atuty. Należy tu chyba z góry wykluczyć sprawowane urzędy, jako jedno z kryteriów doboru. Wydaje się nawet dziwne, że tak zaszczytną funkcję powierzono ludziom, którzy zajmowali mniej eksponowane miejsca w hierarchii urzędniczej Małopolski.

Cześnik krakowski Włodko z Charbinowic herbu Sulima wymieniony jest $\mathrm{w}$ dokumentach na pierwszym miejscu wśród dyplomatów prowadzących te rokowania. Pochodził z rycerskiej rodziny osiadłej w Małopolsce przynajmniej od początku XIII wieku. Ród nie należał do najznamienitszych, niemniej jednak starał się odgrywać pewną rolę polityczną na miarę swoich możliwości. Nie brakowało w każdym razie wśród przodków Włodka z Charbinowic książęcych urzędników. Nie zajmowali oni, co prawda, eksponowanych urzędów, niemniej jednak funkcjonowali oni w małopolskiej elicie władzy okresu rozdrobnienia dzielnicowego. Gospodarczą podstawą działalności rodu był kompleks dóbr z Wierzcho-

27 Analizę składu osobowego polskich poselstw i kryteriów doboru dyplomatów przeprowadzilem w pracy: Dyplomacja Kazimierza Wielkiego. Funkcjonowanie $i$ skład osobowy, Kraków 1985 (maszynopis rozprawy doktorskiej w Oddziale Rękopisów Biblioteki Jagiellońskiej). 
sławicami na czele ${ }^{28}$. Pierwszym znanym właścicielem tych dóbr był komes Strzeszek, cześnik księcia Leszka Białego w latach 1222-1230. Ów Strzeszek występował w otoczeniu księcia krakowskiego kilkakrotnie w latach 1223-1227 ${ }^{29}$. Z nielicznych dokumentów wynika bardzo wyraźnie, że odgrywał pewną rolę polityczną. Po śmierci Leszka Białego należał do wiernych stronników księżny Grzymisławy ${ }^{30}$. Ostatni raz wystąpił w otoczeniu stronników księżny na wiecu w Skaryszewie z Konradem Mazowieckim. Nie wiadomo jaką rolę odegrał później w Małopolsce, więcej bowiem nie występuje w źródłach. Nie wiadomo też, jak liczne potomstwo pozostawił. Źródłowo poświadczony jest tylko jeden z jego synów - Wawrzyniec. Tenże Wawrzyniec świadkował w roku 1256 na dokumencie Bolesława Wstydliwego wystawionym w Zawichoście. Nie piastował żadnego urzędu, a określany był jako „oficialis” syn Strzesz$\mathrm{ka}^{31}$. W latach 1258 - 1259 był podkomorzym sandomierskim ${ }^{32}$. Z urzędu tego przeszedł na podstolego sandomierskiego, będąc nim w latach 1259$1260^{33}$. Następnie (1261-1268) był podkomorzym ponownie, tym razem krakowskim $^{34}$. Z kolei objął urząd łowczego, na którym poświadczony jest w latach $1269-1270^{35}$, nie wiadomo jednak, jak długo go piastował. W roku 1273 poświadczony jest jeden raz jako stolnik sandomierski ${ }^{36}$. $\mathrm{Na}$ początku 1278 roku występuje jako stolnik Bolesława Wstydliwego, a w latach 1278-1279 jako ,camerarius ducisse" ${ }^{37}$. Tę długą karierę urzędniczą zakończył na urzędzie sędziego krakowskiego w latach 1287$1290^{38}$. W tym to roku po raz ostatni wystąpił z tym tytułem na dokumencie Władysława Łokietka ${ }^{39}$. Był to równocześnie jego ostatni występ na małopolskiej widowni politycznej. W tym roku zapewne zmarł.

Dziedzicem dóbr Wawrzyńca został jego syn Klemens. W źródłach po raz pierwszy wystąpił w roku $1278 \mathrm{z}$ urzędem miecznika sandomierskiego. $\mathrm{W}$ tym to roku zakupił za 150 grzywien wieś Charbinowice od swojej krewnej, niejakiej Katarzyny, córki Stefana, syna Iwona z Wielkopolski. Leszek Czarny w nagrodę za zasługi Klemensa, a właściwie jego ojca, nadał

${ }^{28}$ Dzieje Wierzchosławic opracował dr Franciszek Sikora. Za udostępnienie mi maszynopisu do wglądu składam Autorowi w tym miejscu wyrazy podziękowania.

${ }^{29}$ KodKKr $1 \mathrm{nr}$ 13-15; KodMp $1 \mathrm{nr}$ 10, 12; KodMp $2 \mathrm{nr}$ 387, 389; DyplMog nr 4; KodPol $3 \mathrm{nr} 13$.

${ }^{80}$ KodMp $2 \mathrm{nr} 401$.

31 KodMp $2 \mathrm{nr} 451$.

$32 \mathrm{KodKKr} 1 \mathrm{nr} 58-60$.

s3 KodMp $2 \mathrm{nr} 458$.

34 KodKKr $1 \mathrm{nr}$ 62, 79; KodMp $1 \mathrm{nr}$ 60, 62, 63, 66, 77; KodMp $2 \mathrm{nr}$ 470, 471, 472 .

35 KodMp 1 nr 78, 79; KodMp 2 nr 476; KodTyn nr 24; KodPol 3 nr 43.

${ }^{36}$ KodMp $2 \mathrm{nr} 482$.

37 KodKKr $1 \mathrm{nr} 81$, 83; KodMp $1 \mathrm{nr}$ 96; KodMp $2 \mathrm{nr} 485$.

${ }^{88}$ KodTyn nr 24; DyplMog nr 37; KodMp 2 nr 505, 506, 509.

39 KodMp $1 \mathrm{nr} 119$. 
Charbinowicom rozległy immunitet, zwalniając je od ciężarów prawa książęcego ${ }^{40}$. Dobra swoje powiększył znacznie gdy otrzymał od Władysława Łokietka Zasów w roku $1291^{41}$. Po raz ostatni Klemens poświadczony jest u boku Władysława Łokietka w Strzelnie w roku 1293, jako miecznik krakowski. Synem Klemensa był Piotr z Charbinowic znany z dokumentu z roku $1319^{42}$. Ow Piotr był ojcem Włodka z Charbinowic i Nawoja z Zasowa.

Wywód genealogiczny Włodka z Charbinowic pokazuje bardzo wyraźnie, że rodzina pod koniec XIII wieku i na początku XIV zaczęła tracić na znaczeniu. Jest rzeczą bardzo charakterystyczną, że ojciec Włodka nie piastował żadnego urzędu. Włodko pojawił się w źródłach po raz pierwszy w roku 1363 bez żadnego urzędu, jako dziedzic Charbinowic ${ }^{43}$. W dwa lata później stanął ze swoim bratem Nawojem przed sądem ziemskim sandomierskim $\mathrm{w}$ sprawie podziału dóbr ${ }^{44}$. Od połowy roku 1373 Włodko występuje w źródłach jako cześnik krakowski ${ }^{45}$. Urząd ten, jak przypuszczam, zawdzięczał Elżbiecie Łokietkównie, towarzysząc jej w podróżach po Polsce ${ }^{46}$. Z urzędem cześnika krakowskiego łączył od roku 1383 urząd starosty lubelskiego ${ }^{47}$, na którym pozostawał do roku 1387. Tak więc skromny urząd, średniej wielkości posiadłość ziemska oto z czym wchodził Włodko z Charbinowic w epokę jagiellońską. Wydaje się, że genezy jego misji dyplomatycznych należy upatrywać w sprawowaniu urzędu starosty lubelskiego.

W roku 1383 książęta litewscy nadali znaczny przywilej kupcom lubelskim. Otwierał on im drogę na Litwę, pozwalając na rozwinięcie dalekosiężnych kontaktów handlowych z Wilnem i Rygą. Przywilej ten połączył bardzo ściśle z dziejami unii jagiellońskiej Oskar Halecki. Uznał też za pewnik, że Włodko został wydelegowany przez zjazd sieradzki do odbycia poselstwa na Litwę, gdzie miał rozpocząc pertraktacje z wielkim księciem. Niejako przy okazji miał wystarać się o przywilej dla mieszczan lubelskich wystawiony przez książąt litewskich 15 kwietnia tegoż roku ${ }^{48}$. Pogląd Oskara Haleckiego znalazł powszechne uznanie w literaturze ${ }^{40}$. Zakwestionował go jedynie Henryk Paszkiewicz ${ }^{50}$. Wskazał on

40 KodPol $3 \mathrm{nr} 93$

41 KodPol $1 \mathrm{nr}$ 78; DokKujMaz nr 17 s. 129

${ }^{42}$ KodMp $1 \mathrm{nr} 158$.

43 ZDMp $1 \mathrm{nr} 103$.

${ }^{44} \mathrm{KodKKr} 2 \mathrm{nr} 237$.

45 ZDMp $1 \mathrm{nr}$ 148; ZDMp $4 \mathrm{nr} 1019$.

46 ZDMp $1 \mathrm{nr}$ 148, 150, 155; ZDMP $4 \mathrm{nr}$ 1019; KodMp $1 \mathrm{nr} 315$.

47 ZDMp $1 \mathrm{nr}$ 172; ArSang $2 \mathrm{nr} 52$; KodKKr 2 nr 343.

48 O. Halecki, Dzieje unii..., t. 1 s. 95-96; KodMp $3 \mathrm{nr} 931$ (z błędną datą 18 zamiast 15 kwietnia).

49 Por. Historia polityczna Polski, [w:] Encyklopedia polska. Wydawnictwo Polskiej Akademii Umiejętności, t. $5 \mathrm{cz}$. 1, Kraków 1920, s. 452; W. M o s z c z eń s ka, Rola polityczna rycerstwa wielkopolskiego $w$ czasie bezkrólewia po Ludwiku 
słusznie, że między zjazdem sieradzkim a wystawieniem przywileju jest bardzo krótki okres czasu; trudno więc wytłumaczyć ów pośpiech. Sytuacja w roku 1383 była w Polsce na tyle jeszcze niepewna, że trudno było już wtedy myśleć o małżeństwie Jadwigi. Dodać do tego można jeszcze bardzo gorącą atmosferę zjazdu sieradzkiego, gdzie część zebranych wyraziła zgodę na objęcie tronu przez Siemowita IV, księcia mazowieckiego ${ }^{51}$. Wśród jego zwolenników znalazł się również arcybiskup. Jeżeli Małopolanie myśleli już wtedy poważnie o kandydaturze Jagiełły, to jeszcze przed wysłaniem do niego poselstwa, musieli doprowadzić do zneutralizowania opozycji w kraju. Sam plan był na tyle śmiały, że mógł wywołać opory ze strony znacznej części rycerstwa.

Wysunięte zastrzeżenia pod adresem koncepcji Oskara Haleckiego nie umniejszają znaczenia przywileju lubelskiego dla zbliżenia polsko-litewskiego. Należy jednak postawić pytanie, kto odnosił z tego korzyści. Pozwoli ono bowiem sprowadzić całe zagadnienie $\mathrm{w}$ pierwszym rzędzie do stosunków handlowych polsko-litewskich. Dzięki pracy Władysława Semkowicza znamy działalność polityczną i gospodarczą namiestnika wileńskiego Hanula, zdolnego i obrotnego mieszczanina rodem z Rygi ${ }^{52}$. Semkowicz stwierdził mianowicie, że przywilej dla kupców lubelskich został spisany właśnie przez niego. Jako mieszczanin, był zainteresowany sprawami handlowymi. W roku 1383 jedyna droga handlowa z Wilna do Małopolski wiodła właśnie przez Lublin. Droga przez tereny państwa krzyżackiego nie wchodziła w rachubę. Droga przez Podlasie została w roku 1382 zamknięta z powodu wojny Jagiełły z książętami mazowieckimi ${ }^{58}$. Wiosną 1383 roku Litwinom udało się odzyskać Drohiczyn i inne grody podlaskie ${ }^{54}$. Umożliwiło to oczywiście nawiązanie stosunków handlowych. Przywilej dla kupców lubelskich był w interesie zarówno mieszczaństwa litewskiego, jak i lubelskiego. Prawdopodobnie istniał drugi przywilej (rewersał) wystawiony dla kupców wileńskich, który przyznawał im podobne koncesje handlowe. Przywilej taki mógł wystawić dla nich właśnie starosta lubelski. Nie można wykluczyć, że przy tej okazji nawiązał jakieś kontakty z książętami litewskimi i z Hanulem. Ten ostatni był w każdym

Wielkim, „Przegląd Historyczny” 25 (1925) s. 135; W. Maciejewska, jw., s. 42 .

$50 \mathrm{H}$. Paszkiewicz, O genezie..., s. 206 n.

51 Joannis de Czarnkow Chronicon Polonorum, MPH 2 s. 729-730.

${ }^{52} \mathrm{~W}$. S e mkowicz, Hanul namiestnik litewski $i$ jego ród, ,Ateneum Wileńskie" 7 (1930) s. 1-20. Pogląd Semkowicza, jakoby Hanul był pisarzem dokumentów Jagiełły, zakwestionował M. Kosman (Rzekoma dziatalność pisarska Hanula, „Studia Źródłoznawcze” $12: 1967$ s. 149 n.). Warte podkreślenia są ciekawe uwagi tegoż autora o roli mieszczaństwa wileńskiego utwierdzające w przekonaniu o ekonomicznym charakterze przywileju.

53 Joannis de Czarnkow Chronicon Polonorum, MPH 2 s. 729-730; W. Se mkowi c z, jw., s. 9.

54 Tamże, s. $734-735$. 
razie najbardziej zainteresowany rozwojem dalekosiężnego handlu litewskiego. Jest rzeczą zastanawiającą, że ów Hanul wchodził w skład oficjalnego poselstwa Jagiełły do Krakowa w roku 1385 i udał się na Węgry $\mathrm{w}$ towarzystwie właśnie Włodka z Charbinowic. Tak więc o misji dyplomatycznej starosty lubelskiego zadecydowały jego wcześniejsze kontakty z Litwinami. Musiał być znany na Litwie i w Polsce ze swej działalności zmierzającej do nawiązania stosunków handlowych. Przywileje handlowe miały oczywiście podłoże polityczne. Wystarczy wskazać chociażby na okoliczności, w jakich Kazimierz Wielki udzielał koncesji handlowych mieszczanom świdnickim ${ }^{55}$, czy na politykę Ludwika Wielkiego wobec miast polskich $\mathrm{w}$ związku z zabiegami o sukcesję jego córek w Polsce ${ }^{56}$. Można więc powiedzieć, że Włodko działał na rzecz zbliżenia polsko-litewskiego jeszcze przed nawiązaniem oficjalnych rokowań polsko-litewskich. Mógł nawet w pewnym sensie utorować drogę tym rokowaniom. Wysłanie go z misją dyplomatyczną na Węgry w związku z poselstwem Jagiełły nie budzi zdziwienia zważywszy na fakt jego dobrych stosunków z Elżbietą Łokietkówną. Jej to właśnie, jak wspomniałem wyżej, zawdzięczał swoją karierę urzędniczą. Nie można wykluczyć, że znały go tamtejsze kręgi dworskie, co znakomicie mogło ułatwić prowadzone rokowania.

Drugim uczestnikiem poselstwa do Budy oraz późniejszych misji dyplomatycznych był Krystyn z Ostrowa. Ten późniejszy kasztelan krakowski urodził się w czasach Kazimierza Wielkiego około 1352 roku, jak można obliczyć na podstawie jego zeznań złożonych na procesie polsko-krzyżackim ${ }^{57}$. Pierwszy raz w źródłach wystąpił, jako rycerz, w charakterze świadka na dokumencie z $1369 \mathrm{roku}^{58}$. Nie piastował wówczas jeszcze żadnego urzędu. Ponownie pojawił się w źródłach, również bez urzędu, w roku 1378. Wiadomo, że pieczętował się herbem Rawa. Posiadał dobra (zapewne rodowe), których centrum stanowił Ostrów (dzisiejszy Ostrowiec Swiętokrzyski) ${ }^{59}$. Ten nie znany bliżej rycerz musiał dać się poznać jako zręczny polityk posiadający zaufanie rycerstwa, skoro powołano go do sandomierskiej komisji terytorialnej administracji na zawiązanej w roku 1384 konfederacji w Radomsku ${ }^{\text {60 }}$. Komisja sandomierska,

55 Por. J. Dąbrowski, Dzieje polityczne Slqska w latach 1290-1402, [w:] Historia Ślqska od czasów najdawniejszych do roku 1400, t. 1, Kraków 1933, s. 496-497.

${ }^{56}$ KodWp $3 \mathrm{nr}$ 1689; KodKrak $1 \mathrm{nr} 41$.

57 Por. Lites ac res gestae inter Polonos Ordinemque Cruciferorum, ed. T. D z i ały ńs ki, t. 2, Poznań 1855, s. 307.

${ }_{58} \mathrm{ZDMp} 1 \mathrm{nr} 129$.

59 J. W y rozumski, Ostrowski Krystyn, PSB 24 s. 564.

$60 \mathrm{~J} . \mathrm{Szujski}$, Uchwaty zjazdu $w$ Radomsku dnia 2 marca 1384 roku, [w:] Rozprawy Akademii Umiejętności. Wydziat Historyczno-Filozoficzny, t. 1, Kraków 1874 , s. 163 n. Tekst konfederacji w: CodEp $1 \mathrm{nr} 2$. 
podobnie jak komisje dla innych ziem, składała się głównie z urzędników zarządu terytorialnego i przedstawicieli dwóch miast $\mathrm{z}$ danej ziemi. W skład sandomierskiej komisji weszli: Otton - wojewoda sandomierski, Jan - kasztelan sandomierski, Piotr - kasztelan małogojski, Mikołaj Bogoria — kasztelan zawichojski, Prandota - podsędek sandomierski oraz jako jedyny bez urzędu - Krystyn z Ostrowa. Był on zupełnym wyjątkiem w tym względzie wśród wszystkich przedstawicieli rycerstwa całego kraju. Działalność w konfederacji utorowała mu zapewne drogę do misji poselskich. Nietrudno zresztą zrozumieć kierowników polskiej polityki pamiętających czasy Kazimierza Wielkiego, czym kierowali się, powierzając swym reprezentantom poselstwa dyplomatyczne na Węgry i na Litwę. Szukano w pierwszym rzędzie ludzi oddanych prawie oraz znanych na dworach, które mieli odwiedzić. Była to sprawdzona metoda doboru personelu dyplomatycznego.

W roku 1387 Krystyn z Ostrowa poświadczony jest na typowo dworskim urzędzie ochmistrza królowej ${ }^{61}$. Powstaje pytanie, od kiedy zaczął sprawować ten urząd przy królowej; od momentu koronacji, czy dopiero od roku 1387. Nie ma właściwie przeszkód, by przyjąć, że powierzono mu ten urząd zaraz po koronacji królowej. Wtedy to bowiem zaczęto formować dwór królowej, wprowadzając do niego element polski obok przybyłych z Jadwigą Węgrów. Warto zauważyć, że Krystyn z Ostrowa występował z tym tytułem tylko wówczas, gdy towarzyszył królowej w podróży poza Kraków ${ }^{62}$. Mógł więc udać się do Budy jako dworzanin Jadwigi, cieszący się zaufaniem swych mocodawców i ogółu rycerstwa.

Mikołaj Bogoria był trzecim uczestnikiem poselstwa budzińskiego i późniejszych legacji na Litwę. Wśród uczestników misji dyplomatycznej był osobistością najbardziej znaną. Pochodził z wpływowego małopolskiego rodu Bogoriów, który w XIV wieku zdołał skupić w swoich rękach najwięcej małopolskich urzędów ${ }^{63}$. Bogoriowie byli jednym z nielicznych rodów, które konsekwentnie popierały andegaweńską politykę Władysława Łokietka i Kazimierza Wielkiego. Następstwem takiej postawy było ich opowiedzenie się za rządami andegaweńskimi w Polsce. W roku 1374 Mikołaj Bogoria uzyskał kasztelanię zawichojską, niewątpliwie z poręki Elżbiety Łokietkówny. Należał do wiernych jej stronników, towarzyszył królowej w czasie objazdów kraju. Brał udział w wyprawie Ludwika Wielkiego na Ruś w roku 1377. Zalicza się go również całkiem słusznie do grona ścisłych doradców Władysława Opolczyka w czasie jego s. 63 .

61 AGZ $2 \mathrm{nr} 32 ;$ AGZ $3 \mathrm{mr} 74$.

62 A. Strzelecka, O królowej Jadwidze. Studia $i$ przyczynki, Lwów 1933,

${ }_{63} \mathrm{~S}$. Szczur, Uwagi o działainości dyplomatycznej Jarostawa Bogorii, „Nasza Przeszłośc" (w druku). 
rządów namiestniczych ${ }^{64}$. Z polecenia królowej Elżbiety w roku 1383 został wysłany do Wielkopolski wraz z innymi dostojnikami małopolskimi w celu zaprowadzenia spokoju w tej dzielnicy. W rok później figurowal na akcie konfederacji radomszczańskiej, jako reprezentant ziemi sandomierskiej. Z całej jego działalności widać bardzo wyraźnie, że cieszył się zaufaniem dworu węgierskiego, reprezentując jednak interesy polskiej racji stanu. Gdyby Elżbieta miała jakieś wątpliwości co do małżeństwa Jadwigi, to można przypuszczać, że Mikołaj Bogoria mógł je skutecznie rozproszyć.

Przedstawione wyżej kariery trzech uczestników poselstwa budzińskiego pokazują bardzo wyraźnie, że ich wybór przeprowadzono bardzo starannie. Znalazł się wśród nich człowiek cieszący się zaufaniem na dworze budzińskim, człowiek, który miał wcześniej kontakty z Jadwigą, dalej - przedstawiciel rycerstwa sandomierskiego, wreszcie dworzanin młodej królowej.

Czwartym uczestnikiem rokowań polsko-litewskich był $\mathrm{P}$ i ot $\mathrm{r} \mathrm{Sz}$ afraniec z Łuczyc, podstoli krakowski. Został on dołączony do znanej już trójki dyplomatów pod sam koniec negocjacji, brał bowiem udział w poselstwie do Jagiełły w roku 1386. Figuruje jednak wśród wystawców dokumentu dla Jagiełły i to na drugim miejscu, tuż po Włodku z Charbinowic ${ }^{65}$. Brak źródeł nie pozwala określić dokładnie, jaką rolę odegrał w rokowaniach. Sądząc z późniejszych źródeł, musiała ona być znaczna.

Nie potrafimy niestety określić środowiska rodzinnego Piotra Szafrańca. Wywodził się z rodu, który w herbie miał konia. Niesiecki i Piekosiński nazwali ten ród "Starekonie" ${ }^{86}$. Używał tego herbu syn Piotra Szafrańca, również Piotr, który pisał się z Łuczyc i Pieskowej Skały. Euczyce były prawdopodobnie starą posiadłością rodową Szafrańców ${ }^{67}$. Kariera urzędnicza Piotra, podstolego krakowskiego, związana była z panowaniem andegaweńskim w Polsce. Dokumenty dostarczają wielu dowodów, że należał on do bliskich współpracowników Elżbiety Łokietkówny i Ludwika Wielkiego. Z końcem roku 1376 spotykamy go po raz pièrwszy $\mathrm{z}$ godnością podstolego krakowskiego ${ }^{68}$. W latach 1376--1379

64 F. Sikora, Mikołaj z Bogorii, PSB 21 s. 106 n. Por. téz AGZ 2 nr 25 , 26. Mikołaj często występował w otoczeniu Elżbiety Łokietkówny: KodMp $3 \mathrm{nr} 877$, 885, 894, 899, 900 .

65 Akta unii nr 2.

${ }^{66} \mathrm{~K}$. Nies i e cki, Herbarz polski, t. 8, Lipsk 1839, s. 504; F. Piekos ińsk i, Heraldyka polska wieków średnich, Kraków 1899, s. 145.

67 F. Piekosiński, jw., s. 145 n. W latach $1361-1362$ i 1378-1384 na dokumentach prywatnych występuje niejaki Tomasz z Łuczyc, bez urzędu. Sądząc z chronologii występowania, był to brat Piotra (zob. KodPol $3 \mathrm{nr} 126,131,132$; KodMp $3 \mathrm{nr} 905,918,919,936)$. Znany jest też Tomasz, syn Piotra $\left(\mathrm{K}_{\mathrm{K}} \mathrm{KKr} 1 \mathrm{nr}\right.$ 432).

68 DyplMog nr 90. 
często przebywał $u$ boku Elżbiety Eokietkówny ${ }^{69}$. Zasłużył sobie zapewne na łaskę królewską, skoro Elżbieta, wspominając jego wierne służby, zezwoliła na przeniesienie świeżo nabytych przez niego dóbr na prawo niemieckie. Dobra te to Sielce i Klimontów, nabyte przez Piotra Szafrańca od Ottona z Pilczy w roku $1378^{70}$. Panowanie Jadwigi nie przyniosło żadnych zmian w karierze Piotra Szafrańca. Był jej wiernym zwolennikiem. W roku 1384 znalazł się wśród komisarzy powołanych przez Jadwigę do zbadania zarzutów, wysuniętych pod adresem arcybiskupa Bodzęty. Arcybiskup gnieźnieński należał bowiem do tego odłamu społeczeństwa, który w r. 1383 obwołał w Sieradzu królem Polski księcia mazowieckiego Ziemowita. Niefortunne poparcie udzielone księciu piastowskiemu stało się powodem daleko idących komplikacji. Musiał arcybiskup oczyścić się przed zarzutami najpierw przed margrabią Zygmuntem, później przed królową. Trybunał zakończył formalnie prace 12 grudnia 1384 roku, wystawiając odpowiedni dokument zwalniający arcybiskupa od zarzutów ${ }^{71}$. Powołanie Piotra Szafrańca w skład tego gremium dowodzi zaufania do jego osoby nie tylko Jadwigi, ale przede wszystkim faktycznych kierowników polityki polskiej. Oni też, może w porozumieniu z królową, upoważnili Piotra Szafrańca do zaprezentowania ich interesów.

\section{III}

Wymienieni dyplomaci byli pierwszymi oficjalnymi przedstawicielami Królestwa Polskiego, z którymi zetknął się wielki książę Litwy. Zrozumiał zapewne, że na podobnych ludziach będzie musiał oprzeć swoje panowanie. Dyplomaci polscy zapewne również liczyli na dalszą karierę przy nowym władcy. Każde nowe panowanie stwarzało bowiem nowe możliwości awansów na wyższe urzędy, budziło nadzieje na nowe nadania. Przyznać trzeba, że oczekiwania dyplomatów zostały spełnione jeżeli nie całkowicie, to $\mathrm{w}$ dużej części. Wszyscy bowiem, zostali w jakiś sposób wynagrodzeni urzędami lub nadaniami ziemskimi.

Nagradzanie dyplomatów za udane misje dyplomatyczne było starą praktyką. Wystarczy odwołać się do czasów Kazimierza Wielkiego, który tę praktykę upowszechnił. Jego czołowy dyplomata Jan Pakosławic otrzymał w roku 1352 ogromne nadanie ziemskie w zamian za udaną misję dyplomatyczną do chana Tatarów. Warto dodać, że było to największe królewskie nadanie dla osoby prywatnej ${ }^{72}$. Biskup krakowski Jan Grotowic i pleban Małogoszczy Jan otrzymali królewskie nadania za udaną

\footnotetext{
${ }^{69}$ KodMp $1 \mathrm{nr} 339$, 350; KodMp $3 \mathrm{nr}$ 910; ZDMp 1 nr 150, 154.

70 KodMp 1 nr 350, 339.

71 KodWp 3 nr 1825; S. Trojanow ski, Bodzęta, PSB 2 s. 183.

72 KodPol 1 nr 119.
} 
misję dyplomatyczną w Awinionie ${ }^{78}$. W XIV wieku rozpowszechniony był zwyczaj wynagradzania dyplomatów przez obce dwory w zamian za popieranie ich interesów. Nadania te miały charakter polityczny, ale nie budziły zgorszenia, należały bowiem do powszechnie akceptowanego obyczaju dyplomatycznego. Z Kroniki Janka z Czarnkowa wiemy o nadaniach Karola Roberta dla Małopolan popierających jego plany sukcesyjne na dworze Kazimierza Wielkiego ${ }^{74}$. Margrabia brandenburski nadał Mikołajowi z Biechowa rentę pieniężną $\mathrm{w}$ zamian za popieranie jego interesów na dworze polskim ${ }^{75}$. Taki sam cel miało obdarowanie przez Karola IV Jana Jury, wojewody sandomierskiego, dwoma starostwamı w Sudetach ${ }^{76}$.

Nie inaczej postępował Władysław Jagiełło. Był on w sytuacji o tyle trudniejszej, że nie był dziedzicem Królestwa Polskiego, lecz, jako król elekcyjny, musiał dopiero zjednywać sobie zwolenników. W takiej sytuacji swoistej wymowy nabiera fakt, że jedno z pierwszych nadań uczynionych przez króla to nadanie dla Piotra Szafrańca. Królewski dokument wystawiony został w Krakowie 3 marca 1386 roku, na dzień przed koronacją królewską. Jagiełło występujący jeszcze jako ,gubernator Regni Poloniae" opatrzył dokument swoją pieczęcią litewską. Piotr Szafraniec za wierne służby otrzymał w dziedziczne posiadanie królewski zamek Pieskową Skałę „,cum omnibus villis, molendinis, proventibus et utilitatibus suis universis" 77 oraz wieś Sułoszowę należącą do tego właśnie zamku.

W niedługim czasie również inni panowie małopolscy, którzy przyczynili się do wyniesienia Jagiełły na tron polski, zostali hojnie obdarowani. Wśród nich pierwsze miejsce zajmują Leliwici - Tarnowscy. W roku 1386 otrzymali oni od króla przywileje i nadania górnicze ${ }^{78}$. Wśród przedstawicieli tego rodu największe uposażenie ziemskie uzyskał Jan z Tarnowa, wojewoda sandomierski, starosta generalny ruski i kasztelan krakowski ${ }^{79}$. Tarnowscy bowiem, według określenia Jagiełły, pracowali ,ad nostros et regni nostri Poloniae instaurandos honores", co - jak słusznie zinterpretowano - odnosi się do wyniesienia Władysława Jagiełły na tron polski ${ }^{80}$.

W podobny sposób określił król zasługi Włodk a $\quad \mathrm{z} \quad \mathrm{C}$ ha r bin owi c, również hojnie go obdarzając. W roku 1386 otrzymał on od króla

73 KodKKr 1 nr 172; ZDMp 4 nr 927.

74 Joannis de Czarnkow Chronicon Polonorum, MPH 2 s. 638.

75 KodWp $2 \mathrm{nr} 1244$. nr 16.

76 Regesta Bohemiae et Moraviae, ed. J. Emlex [...], t. 6, Pragae 1855-1869,

77 KodMp 4 nr 969.

78 Tamże nr 972.

79 KodMp $4 \mathrm{nr}$ 991; ArSang $2 \mathrm{nr}$ 59; KodMp $4 \mathrm{nr} 1022$.

80 O. Halecki, Dzieje unii..., t. 1 s. 97. 
rozległe terytorium, którego centrum stanowił zamek w Ogrodzieńcu w powiecie lelowskim. W skład kompleksu ziemskiego, obok wspomnianego „,castrum", wchodziły dwa miasta: Koczurów i Włodowice, i osiem wsi, do tego ,fortalicium” Wiesiółka z dwoma wsiami oraz wieś Konopnica w ziemi lubelskiej ${ }^{81}$. Nie ulega bowiem wątpliwości, że nadanie to miało ścisły związek z misjami dyplomatycznymi Włodka z Charbinowic oraz z jego staraniami o powołanie Władysława Jagiełły na tron polski. Jego zasługi musiały być proporcjonalne do wielkości nadania. Otrzymane dobra stały się podstawą gospodarczej i politycznej działalności jego synów.

Dwóch pozostałych dyplomatów wynagrodził Władysław Jagiełło wysokimi urzędami, włączając ich przez to w krąg ścisłej elity władzy w Małopolsce. Można bez przesady powiedzieć, że prawdziwą karierę na działalności dyplomatycznej zrobił skromny „dzierżawca kazimierski”" Krystyn z Ostrowa. W krótkim czasie osiągnął on bowiem szybko awansując - hierarchicznie najwyższy urząd w kraju, a mianowicie kasztelanię krakowską. Awans na pierwszy poważniejszy urząd otrzymał, będąc ochmistrzem ḳrólowej, stosunkowo późno, bo w roku 1392. Został wtedy mianowany kasztelanem sandomierskim, a pozostawał na tym urzędzie do początków 1406 roku. Począwszy od marca tegoż roku występował jako wojewoda sandomierski. Awans na kasztelanię krakowską otrzymał na dwa miesiące przed bitwą grunwaldzką i pozostawał na tym urzędzie do końca życia. Z wymienionymi urzędami łączył dwukrotnie inne funkcje. W latach 1407-1409 był starostą sandomierskim, a w latach 1411-1418 pełnił obowiązki starosty krakowskiego. Wyliczone urzędy, pełnione przez Krystyna z Ostrowa ${ }^{82}$, nie obrazują oczywiście odgrywanej przez niego roli politycznej. Działalność ta bowiem wykraczała daleko poza obowiązki sprawowanych urzędów. Wysuwano w historiografii sugestie, że Krystyn z Ostrowa, obok takich osobistości, jak Dymitr z Goraja czy Jan z Tarnowa, należał do tej grupy panów małopolskich, którzy reprezentowali inkorporacyjne koncepcje w stosunku do Litwy. Koncepcjom tym miał się Jagiełło przeciwstawiać jawnie lub skrycie, co miało prowadzić do rozbieżności między nim a wymienioną grupą ludzi ${ }^{83}$. Jeżeli nawet takie rozbieżności faktycznie istniały, to przyznać trzeba, że współpraca Władysława Jagiełły z jego kasztelanem krakowskim na tym nie ucierpiała. Nie ulega wątpliwości, że Krystyn z Ostrowa pozostał wierny koncepcjom politycznym panów małopolskich z końca XIV wieku. Był gorącym rzecznikiem unii polsko-litewskiej. Brał czyn-

81 ZDMp $6 \mathrm{nr} 1521$.

82 J. Wyrozumski, jw., s. 564; K. Fedorowicz, Dostojnicy i urzędnicy świeccy województwa krakowskiego w latach 1374-1506, [w:] Archiwum Komisji Historycznej, t. 8, Kraków 1898, s. 13-15, 100, 167, 182.

83 Por. W. Dw orzaczek, jw., s. 107. 
ny udział w zjazdach, które umacniały i precyzowały charakter układów krewsko-wołkowyskich, przyczyniając się do ściślejszego zespolenia Korony $\mathrm{z}$ Litwą ${ }^{84}$. W akcie unii horodelskiej przyjął do swego herbu kasztelana wileńskiego Minigajłę ${ }^{85}$. Antyluksemburskie i antykrzyżackie poglądy Krystyna z Ostrowa stanowiły zapewne płaszczyznę współpracy z Władysławem Jagiełłą. Brał czynny udział w tym nurcie polityki zagranicznej króla ${ }^{86}$. Powierzane mu misje dyplomatyczne świadczą o dużym zaufaniu Władysława Jagiełły do człowieka, który przyczynił się do wyniesienia go na tron polski. Krystyn z Ostrowa był jedynym ze znanej czwórki posłów, któremu dane było oglądać owoce swych dyplomatycznych zabiegów w Budzie i w Wilnie. Rezultaty działań pozostałych uczestników mogli oglądać ich synowie; dzięki działalności politycznej swoich ojców doszli oni do znacznych stanowisk i urzędów w państwie Władysława Jagiełły.

Najstarszy uczestnik zabiegów dyplomatycznych z lat 1384-1386, kasztelan zawichojski Mikołaj Bogoria, niedługo po koronacji Władysława Jagiełły uzyskał kastztelanię wiślicką ${ }^{87}$. Dzierżył ją do swej śmierci, tj. do roku 1388. Król, zapewne w tẹn sposób wynagradzając jego zasługi, mianował go marszałkiem dworu, a w 1387 nadał mu godność marszałka Królestwa ${ }^{88}$. Podobnie jak inni dyplomaci, był uczestnikiem ruskiej wyprawy królowej Jadwigi ${ }^{89}$. Jego działalność polityczna i poglądy na charakter unii zgodne były z zapatrywaniami Władysława Jagiełły. Mikołaj nie był zwolennikiem koncepcji inkorporacji Litwy, a raczej opowiadał się za ekspansją wschodnią. Pisano o nim, że należał do tych, ,którzy wyszli ze szkoły politycznej ostatniego Piasta i rozwijali jego program ekspansji wschodniej ${ }^{90}$. Był kasztelan wiślicki w drugiej połowie XIV wieku najwybitniejszym przedstawicielem Bogoriów, a zarazem ostatnim członkiem tego znakomitego rodu rycerskiego, odgrywającego ważną rolę polityczną. Wraz z jego śmiercią zszedł ze sceny politycznej ród, który jeszcze w czasach Kazimierza Wielkiego zdołał obsadzić swymi przedstawicielami najwięcej małopolskich urzędów, nie mówiąc o godności arcybiskupa. Mikołajowi dane było jednak doprowadzić do zbliżenia polsko-litewskiego, do czego tak usilnie dążył współpracujący z Bogoriami Kazimierz Wielki w ostatnich latach swego panowania.

84 Akta unii, nr 44, 50.

${ }^{85} \mathrm{~W}$. Semk owicz, O litewskich rodach bojarskich zbratanych ze szlachta pols,kq $w$ Horodle $w$ r. 1413, „Miesięcznik Heraldyczny” 7 (1914) s. 51 n.

86 Por. J. W y r o zum ski, jw., s. 565 .

${ }_{87}$ ZDMp $6 \mathrm{nr} 1518,1524,1528,1529,1533,1534,1539,1540,1541,1542$.

88 ZDMp $6 \mathrm{nr} 1529$.

$89 \mathrm{AGZ} 3 \mathrm{nr} 43$.

90 O. Halecki, Dzieje unii..., t. 1 s. 98; W podobnym tonie charakteryzuje działalność Mikołoja z Bogorii Z. W d ow is zews ki (Ród Bogoriów w wiekach średnich, „Rocznik Polskiego Towarzystwa Heraldycznego we Lwowie” 9: $1930 \mathrm{~s}$. 78 n.). 
Cześnik krakowski Włodko z Charbinowic, obdarowany przez Władysława Jagiełłę, pozostał na zajmowanym dotychczas urzę-

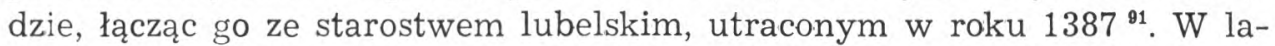
tach 1386-1391 często przebywał u boku Władysława Jagiełły ${ }^{\text {22 }}$. Towarzyszył królowi na początku roku 1387 w podróży na Litwę. W rok później na jego prośby Władysław Jagiełło potwierdził mu nadanie Ogrodzieńca z przyległościami oraz znacznie je rozszerzył: cześnik krakowski otrzymał cło w Ogrodzieńcu, królewską wieś Rodaki leżącą niedaleko Ogrodzieńca, pół królewskiej wsi Klucze położonej na tym samym terenie, oraz dom królewski na wzgórzu zamkowym ${ }^{\text {93 }}$. Zmarł Włodko z Ogrodzieńca po roku 1391. Ostatni raz z tytułem cześnika świadkował na dokumencie królewskim w październiku tegoż roku ${ }^{94}$. W kilka lat później występuje w źródłach wdowa po dziedzicu Charbinowic ${ }^{95}$. Ona też zarządzała całymi dobrami pozostawionymi przez Włodka, przynajmniej do roku 1400. Z małżeństwa z Halszką (Elżbietą) miał Włodko czterech synów: Piotra, Bartosza, Stanisława i Jana. Wszyscy znaleźli się na różnych urzędach w czasach Władysława Jagiełły. Kariery synów Włodka z Charbinowic są o tyle interesujące, że można dzięki nim śledzić pewien szerszy proces mający ścisły związek z unią polsko-litewską. Wyrastali synowie cześnika krakowskiego w cieniu wielkich wydarzeń. Przesuwały się granice państwa, otwierały się nieznane dotąd możliwości prowadzenia działalności na wschodnich kresach. Tam też skierowali swoje zainteresowania, mimo pełnionych w Małopolsce urzędów.

Najstarszy syn dyplomaty dość wcześnie związał się z dworem królewskim. Niewątpliwie pozycja zajmowana przez ojca ułatwiła mu karierę. Piotr jeszcze za życia ojca, nie piastując żadnego urzędu, świadkował na królewskich dokumentach ${ }^{96}$. W roku 1403 otrzymał urząd podstolego sandomierskiego, sprawowany do roku $1427^{97}$. Równocześnie z tym urzędem pełnił funkcję i obowiązki królewskiego starosty na Podolu. W dniu 24 sierpnia 1401 roku poświadczony został po raz pierwszy jako starosta halicki i śniatyński. Ostatni raz wystąpił na tym urzędzie w październiku $1404 \mathrm{roku}^{98}$. Jego władza starościńska rozciągała się również na Koło-

${ }^{91}$ Ostatni raz został poświadczony na tym urzędzie 26 czerwca 1387 roku (KodKKr $2 \mathrm{nr} 343$ ).

92 Zob. ZDMp $4 \mathrm{nr} 1019 ; 6 \mathrm{nr}$ 1518, 1528, 1530, 1556; $8 \mathrm{nr}$ 2541; ArSang ¿ $\mathrm{nr}$ 62; AGZ $2 \mathrm{nr} 16 ; 3 \mathrm{nr} 43$; KodKWil $\mathrm{nr} 6$.

93 ZDMp 6 nr 1548.

94 Materiały archiwalne wyjęte gtównie $z$ Metryki Litewskiej od 1348 do 1607 roku, wyd. A. Prochaska, Lwów 1890, nr 16.

$95 \mathrm{~F}$. Pi ek os iński, Zapiski sadowe województwa sandomierskiego $z$ lat 1395-1444, [w:] Archiwum Komisji Prawniczej, t. 8 cz. 1, Kraków 1907, nr 128, 130, 251; StPPP $8 \mathrm{nr} 317,319,10043$.

${ }_{96}^{6}$ ZDMp $6 \mathrm{nr} 1564,1569,1633,1679,1661$. Por. K. Male c z yński, Urzędnicy grodzcy $i$ ziemscy lwowscy w latach 1352-1783, Lwów 1938, s. 27.

97 Urzędnicy, $\mathrm{nr} 326$.

98 AGZ 2 ar 31. Nie wiadomo jak długo pełnił on tę funkcję. Jego następca 
myję ${ }^{99}$. W latach 1405-1409 nie używa już tytułu starosty, lecz tytułuje się podstolim sandomierskim ${ }^{100}$. W latach $1410-1411$ ponownie wystąpił jako starosta, tym razem Trembowli ${ }^{101}$. Panuje w literaturze przekonanie, że Piotr Włodkowic był ostatnim starostą Podola, a jego odwołanie łączy się z katastrofą polityczną biskupa krakowskiego Piotra Wysza ${ }^{102}$. Wydaje się jednak, że zachodzi tu utożsamienie postawy Piotra z jego bratem Bartoszem, ożenionym z siostrzenicą biskupa krakowskiego i należącym do jego zwolenników. Piotr był raczej, jak wynika to z jego działalności, zwolennikiem Władysława Jagiełły. Od początku 1425 roku występował jako starosta lwowski. Zastąpił na tym stanowisku Spytka z Tarnowa, który pełnił ten urząd do roku 1424. Pełniąc obowiązki starosty lwowskiego, do roku 1427 używał tytułu starosty generalnego ruskiego ${ }^{103}$. Był to już ostatni jego urząd sprawowany na Rusi. Zmarł po roku 1430. Synowie jego pozbyli się Charbinowic i osiedli na Rusi. W roku 1467 Charbinowice zapisane są jako dobra oprawne Barbarze, żonie Stanisława z Tęczyna, córce Zawiszy Czarnego z Garbowa ${ }^{104}$. Ów sławny rycerz i domownik Zygmunta Luksemburskiego był współrodowcem Piotra Włodkowica. Pojął on za żonę Barbarę, bratanicę Piotra Wysza. Siostra owej Barbary była żoną Bartosza z Wierzchosławic i Charbinowic, drugiego $z$ kolei syna dyplomaty ${ }^{105}$.

Bartosz z Charbinowic związany był z Małopolską. Od roku 1411 sprawował urząd podkomorzego sandomierskiego. Na urzędzie tym pozostawał do marca $1421 \mathrm{roku}^{106}$. Po tym roku w źródłach więcej nie występuje. Zmarł prawdopodobnie bezdzietnie, bo majątek jego przypadł bratankom. Obok urzędu podkomorzego sandomierskiego, na którym jest dobrze poświadczony, pełnił około roku 1414 urząd ochmistrza dworu królowej Anny ${ }^{107}$. Na jego karierę urzędniczą wpłynęła niewątpliwie sprawa usunięcia Piotra Wysza z biskupstwa krakowskiego i powołania na nie Wojciecha Jastrzębca. Bartosz należał do przeciwników nowego biskupa, czemu dawał publicznie wyraz. Długosz barwnie opisał zjazd w Łęczycy w ro-

poświadczony jest dopiero w roku 1409. Był nim Jan ze Szczekocin (Urzędnicy, $\mathrm{nr} 327)$.

90 AGZ $5 \mathrm{nr} 101$.

100 AGZ $2 \mathrm{nr} 36 ; 3 \mathrm{nr} 80 ; 4 \mathrm{nr} 23$.

101 AGZ $5 \mathrm{nr} 24,25$.

102 K. Pi otrowicz, Charbinowski Bartosz, PSB 3 s. 263.

$103 \mathrm{AGZ} 10 \mathrm{nr} 563 ; 7 \mathrm{nr} 33,35 ; 3 \mathrm{nr} 101$; Matricularum Regni Poloniae Summaria, wyd. T. Wierzbowski, t. 4, Warszawa 1919, nr 4210, 18833. O starostach na Rusi por.: K. Przyboś, Urzędnicy ziemscy województwa ruskiego, „Studia Historyczne” 28 (1985) s. 510.

104 StPPP $2 \mathrm{nr} 3878$.

105 S. Ki jak, Piotr Wysz, biskup krakowski, Kraków 1933, s. 2.

108 KodWp $5 \mathrm{nr} 239$; KodMp $4 \mathrm{nr} 1198$, 1117; ZDMp $5 \mathrm{nr} 1278,1284 ; 6 \mathrm{nr}$ 1679, 1798; Dokumenty klasztoru PP. Norbertanek $w$ Imbramowicach $z$ lat 12281450, wyd. Z. Kozłowska-Budkowa, [w:] Archiwum Komisji Historycznej, t. 16, Kraków 1948, z. $2 \mathrm{nr} 15$.

107 Zob. przypis $\mathrm{nr} 102$. 
ku 1420, gdzie podkomorzy krakowski zaatakował publicznie biskupa, broniąc sprawy króla „ostrzej niż należało”. Przemówienie Bartosza spowodowało tumult i bójkę na sali. Rozruchy miały, według Długosza, przenieść się aż do miasta ${ }^{108}$. Niefortunne wystąpienie nie przysporzyło Bartoszowi zwolenników, zwłaszcza że Wojciech Jastrzębiec pogodził się z królem; przyczyniło się zaś do zakończenia kariery Bartosza.

Trzeci syn Włodka z Charbinowic obrał rzemiosło rycerskie. W źródłach znany jest jako miecznik sandomierski w latach $1429-1435{ }^{109}$. Zmarł bezpotomnie po roku 1435. Urząd otrzymał dość późno, już jako znany i zasłużony rycerz. Występował w źródłach często $\mathrm{z}$ braćmi w sprawach majątkowych ${ }^{110}$. W latach 1389, 1398, 1395 występował jakiś Stanisław, burgrabia z Ogrodzieńca ${ }^{111}$. Nie ma jednak pewności, czy jest on identyczny ze Stanisławem, synem Włodka, bo równie dobrze mógł to być burgrabia mianowany przez Włodka, jako zarządca dóbr. Sam Włodko brał udział w znanej bitwie pod Grunwaldem, walcząc w szeregu przedchorągiewnych rycerzy, wśród których znajdował się również jego wspólrodowiec Zawisza Czarny ${ }^{112}$. Jego kampania wojenna zakończyła się dopiero pod Koronowem. Z rozkazu króla pozostał w tym grodzie wraz z polską załogą. Z relacji Długosza wynika, że Stanisław wraz z Mikołajem Synowcem opuścili Koronowo, przedostali się do króla, przebywającego w Inowrocławiu, i donieśli mu o niebezpieczeństwie, w jakim znalazła się polska załoga. Tymczasem zapiska $\mathrm{z}$ ksiąg wiślickich, mówiąca o bitwie pod Koronowem, stwierdza, że Stanisław z Charbinowic opuścił Koronowo ,non causa timoris alicuius, sed per rectores illius vexilli alias przes hetmani fuerat destinatus" ${ }^{113}$.

Działalność Jana, czwartego syna Włodka z Charbinowic, związana była z ziemiami ruskimi. Pisał się z Charbinowic, Kniehnic i Pisar. Występował też jako Kniehnicki i Knyhnicki ${ }^{114}$. W latach $1435-1439$ był podstolim lwowskim, a od czerwca 1439 do listopada 1461 występował jako starosta halicki ${ }^{115}$.

108 J. Długosz, Annales seu Cronicae incliti regni Poloniae, l. IX-XI, Varsaviae 1985 , s. 141 .

${ }_{100} \mathrm{~K}$. F e d o r o w i c z, jw., s. 201.

110 F. Piekosiński, Zapiski sqdowe..., $\mathrm{nr}$ 397, 462; StPPP 2 nr 972, 953; $8 \mathrm{nr} 8298$ (uw. 244 s. 462).

111 Wojewódzkie Archiwum Państwowe Kraków, Terrestria Cracoviensia 1 C s. 379/4, 406/13, 424/3.

112 S. M. Kuczyński, Wielka wojna z Zakonem krzyżackim $w$ latach 1409-1411, Warszawa 1955, s. 278 n.

118 Por. J. Długosz, jw., s. 175; W. Semkowicz, Nieznana zapiska o bitwie pod Koronowem, "Kwartalnik Historyczny” 24 (1910) s. 528-531.

114 Urzędnicy, nr 1061. Kniehnice były ruską posiadłością Włodka z Charbinowic może jeszcze z nadania Kazimierza Wielkiego, jak przypuszcza F. Sikora (zob. wyżej przypis 28). W roku 1403 synowie Włodka sprzedali tę posiadłość (StPPP 2 nr 972).

$115 \mathrm{~K}$. M a le c z yń s ki, jw., s. 128; Urzędnicy, nr 74, 1061. 
Pokolenie wnuków Włodka z Charbinowic nie odgrywało już większej roli w życiu politycznym kraju. Związane $z$ Rusią, tam prowadziło działalność gospodarczą, jak wielu innych podobnych im rycerzy rodem z Małopolski czy Mazowsza. Znając kariery i działalność publiczną Włodka z Charbinowic i jego synów, można postawić pytanie, czy rzeczywiście ród ten zrobił karierę dzięki unii polsko-litewskiej. Nie ulega wątpliwości, że działalność dyplomatyczna Włodka otworzyła nowy rozdział nie tylko dziejów Polski, ale także rodu Sulimów. Po względnej prospericie w okresie rozdrobnienia dzielnicowego przyszły lata trudniejsze. Nie słychać nic o działalności Sulimów za Kazimierza Wielkiego. Nie wyróżniali się niczym szczególnym wśród licznych podobnych im małopolskich rodów. Dopiero w czasach Władysława Jagiełły, dzięki jego nadaniom dla Włodka, Sulimowie uzyskali solidne podstawy gospodarcze do swej działalności. Niewątpliwie działalność dyplomatyczna starosty lubelskiego otworzyła drogę do urzędów jego synom. Była to jednak aktywność polityczna na krótką metę, na jedno pokolenie. Nie zdołali też nigdy synowie Włodka wejść do ścisłej elity władzy, funkcjonując na urzędach średniego szczebla.

O prawdziwej karierze można natomiast mówić w przypadku czwartego dyplomaty Piotra Szafrańca z Łuczyc, a właściwie jego synów. Nie ulega bowiem wątpliwości, że zawdzięczali ją w dużej mierze działalności ojca. Działalność Szafrańców jest o tyle interesująca, że można ją w pewnym sensie porównywać z działalnością potomków Włodka z Charbinowic, przynajmniej w punkcie wyjścia. Sądząc z chronologii występowania w źródłach, obaj dyplomaci byli mniej więcej w tym samym wieku, zmarli również prawie w jednym czasie. Podobieństw jest oczywiście więcej. Zajmowali urzędy średniego szczebla. Związani byli z Elżbietą Łokietkówną i Andegawenami, obaj zostali przez Władysława Jagiełłę wynagrodzeni, wreszcie obaj pozostali na tych samych urzędach aż do śmierci. Można powiedzieć, że stworzyli swą działalnością dobre podstawy do karier dla swoich synów i wnuków ${ }^{116}$. Jak wspomniano wyżej, Piotr Szafraniec pozostał za panowania Władysława Jagiełły na zajmowanym dotychczas urzędzie podstolego krakowskiego. Przebywał w otoczeniu dworu królewskiego. Jego obecność poświadczają liczne dokumenty, na których występował jako świadek ${ }^{117}$. Trudno powiedzieć, na ile angażował się $\mathrm{w}$ życie polityczne kraju. Wygląda raczej na to, że wykorzystując swoją pozycję zabiegał o powiększenie własnych posiadłości. W roku 1395 Władysław Jagiełło nadał jemu i jego spadkobiercom miasto Secomin i wieś Bichniów położoną niedaleko tego miasta. W rok

116 Obaj dyplomaci mieli po czterech synów (zob. KodKKr $1 \mathrm{nr} 432$, a także wyżej s. 199 nn.).

117 KodKKr $2 \mathrm{nr} 335,331 ;$ AGZ $3 \mathrm{nr} 43 ; 2 \mathrm{nr} 16,20 ; 5 \mathrm{nr} 21$. 
później podstoli krakowski wystarał się o potwierdzenie tego nadania przez Jadwigę ${ }^{118}$. Pod koniec życia jawi się Piotr Szafraniec nie tyle jako polityk, ale jako zapobiegliwy gospodarz, który stara się przysporzyć majątku swoim czterem synom, dziedzicom rodzinnych Łuczyc. Zmarł w początkach roku $1398^{119}$. W listopadzie Piotr podstoli krakowski, Jan kanonik krakowski, Tomasz i Stanisław ,heredes de Luczicze, fratres germani nati Petri dicti Szaffranecz subdapiferi olim Cracoviensis", uczynił pobożny zapis dla katedry krakowskiej. W roku 1400 ci sami bracia ufundowali ołtarz w katedrze krakowskiej ${ }^{120}$.

Dwaj synowie Piotra Szafrańca, Piotr i Jan, zrobili w niedługim czasie szybkie kariery polityczne. Ich przedstawienie wymagałoby osobnego opracowania. W tym miejscu wypada tylko je zasygnalizować. Najstarszy syn Piotr odziedziczył po ojcu nie tylko imię, ale również urząd podstolego krakowskiego. W późniejszych latach pełnił kolejno urzędy podkomorzego krakowskiego, wojewody sandomierskiego, starosty krakowskiego, łęczyckiego, chęcińskiego, sieradzkiego, a w końcu wojewody krakowskiego w latach 1433-1437 ${ }^{121}$. Jego brat Jan Szafraniec, przechodząc przez liczne godności kościelne, został w roku 1423 kanclerzem krakowskim i sprawował ten urząd aż do roku 1433, tj. do swej śmierci ${ }^{122}$. Sprawowanie przez braci tak wysokich urzędów zapewniało im niekwestionowany wpływ na politykę zagraniczną. Właściwie to oni kierowali tą polityką w ostatnich latach Władysława Jagiełły, tworząc własne stronnictwo polityczne ${ }^{128}$. Działało ono na rzecz osłabienia pozycji Luksemburgów w Czechach i w Polsce.

Byli Szafrańcowie nie tylko politykami i dyplomatami, ale również opiekunami nauki i kultury. Wiele zawdzięcza im Uniwersytet w Krakowie, którego stali się hojnymi benefaktorami. Jan Szafraniec został w roku 1404 piątym z kolei rektorem Uniwersytetu ${ }^{124}$. W ten sposób zbiegły się działania ojca i synów. Ojciec przygotowywał wstępne porozumienia z wielkim księciem Litwy, które otworzyły drogę do unii dwóch państw. Synowie, dzięki zapisom, przyczynili się do rozwoju uczelni,

118 AGZ $5 \mathrm{nr} 21,22$.

119 K. Fedorowicz, jw., s. 89.

120 KodKKr $1 \mathrm{nr} 432$; ZDKKr $2 \mathrm{nr} 143$.

$121 \mathrm{~K}$. Fedorowicz, jw., s. 90,28 n.; W. Dworzaczek, Genealogia, Warszawa 1959, tablica 108. Zob. też I. Sułk owska-Kurasiowa, Doradcy Władysława Jagietty, [w:] Społeczeństwo Polski średniowiecznej, pod red. S. K. K u c z y ńs k i e g o, t. 2, Warszawa 1982, s. 212.

122 Wyczerpujące przedstawienie działalności i kariery Jana Szafrańca dała J. Krzyżaniakowa: Kancelaria królewska Władysława Jagielty, cz. 2, Poznań 1978 , s. 95-105.

123 Por. E. Maleczyńska, Społeczeństwo polskie pierwszej połowy XV wieku wobec zagadnień zachodnich, Wroclaw 1947, s. 95-135 (Szafrańce).

$124 \mathrm{Z}$. Kozłowska-Budkowa, Odnowienie Jagiellońskie Uniwersytetu, [w:] Dzieje Uniwersytetu Jagiellońskiego w latach 1364-1764. t. 1, Kraków 1964, s. 51 .

15 - Analecta Cracoviensia 
która przygotowywała kadry do pracy chrystianizacyjnej na Litwie. Można powiedzieć, że utrwalali $w$ ten sposób dzieło zapoczątkowane przez ojca.

\author{
WYKAZ SKRÓTÓW \\ WYDAWNICTW ŹRÓDEOWYCH CYTOWANYCH W PRZYPISACH
}

AGZ - Akta grodzkie i ziemskie z czasów Rzeczpospolitej Polskiej z Archiwum tzw. Bernardyńskiego we Lwowie, edd. O. Pietruski, X. Liske, t. 1-19. Lwów 1868-1906.

Akta unii - Akta unii Polski z Litwa 1385-1791, edd. St. Kutrzeba, Wł. S e mkowicz, Kraków 1932.

ArSang - Archiwum książąt Lubartowiczów-Sanguszków w Stawucie, edd. L. $\mathrm{R}$ a d zi miński, B. Gor czak, t. 2, Lwów 1888.

CodEp - Codex epistolaris saeculi XV, edd. A. Sokołowski, J. Szujski, A. Lewicki, t. 1-3, Kraków 1875-1894.

DokKujMaz - Dokumenty kujawskie $i$ mazowieckie przeważnie $z$ XIII wieku, ed. B. Ulanowski, Kraków 1887.

DyplMog - Monografia opactwa Cystersów we wsi Mogile, cz. 2: Zbiór dyplomów klasztoru mogilskiego, ed. E. J a n o ta, Kraków 1867.

KodKKr - Kodeks dyplomatyczny katedry krakowskiej sw. Wactawa ed. F. Piekosiński, t. 1-2, Kraków 1874-1883.

KodMp - Kodeks dyplomatyczny matopolski, ed. F. Piekosiński, t. 1-4, Kraków 1876-1905.

KodPol - Kodeks dyplomatyczny Polski od najdawniejszych czasów aż do $r$. 1506, edd. L. Rzyszczewski, A. Muczkowski, J. Bartoszewicz, t. 1-3, Warszawa 1847-1858.

KodTyn - Kodeks dyplomatyczny klasztoru tynieckiego, edd. W. Kętrzyński, St. Smolka, Lwów 1875.

KodWp - Kodeks dyplomatyczny wielkopolski [...], ed I. Z a krzew sk i, t. 1-4, Poznań 1877-1881.

MPH - Monumenta Poloniae historica.

MPH s. n. - Monumenta Poloniae historica. Series nova.

PSB - Polski słownik biograficzny.

Urzędnicy - Urzędnicy województwa ruskiego XIV-XVIII w. (ziemia halicka, lwowska, przemyska $i$ sanocka), opracował K. Przy boś, Wrocław 1986.

ZDKKr - Zbiór dokumentów katedry i diecezji krakowskiej, wyd. S. Kuraś, Cz. 1-2, Lublin 1965-1973.

ZDMp - Zbiór dokumentów małopolskich, wyd. S. Kuraś, I. Sułkowska-Kurasiowa, t. 1-8, Kraków-Warszawa-Wrocław 19621975. 
LES NÉgOCIATEURS DE L'UNION ENTRE LA POLOGNE ET LA LitUANIE ET LEURS CARRIERES

\section{Rés u m é}

L'auteur de cet article présente les diplomates polonais qui furent directement engagés dans les négociations diplomatiques précédant le traité de Krewo. Durant ces pourparlers, le côté polonais fut représenté par Krystyn d'Ostrow, Wlodko de Charbinowice, Mikołaj, châtelain de Zawichost et Piotr Szafraniec. Après avoir analysé leurs carrières, leurs liens familiaux et leur activité, on peut conclure qu'ils ne furent pas choisis par hasard comme négociateurs. Ils étaient étroitement liés à l'élite qui était au pouvoir en Petite Pologne dont dépendait la politique étrangère. Le fait qu'ils prirent part aux négociations diplomatiques influença fort leurs carrières. Après la signature des traités et le couronnement de Wladyslaw Jagellon, ils obtinrent de riches domaines. De cette époque datent leurs brillantes carrières administratives (Krystyn d'Ostrów, Piotr Szafraniec). Sans doute furent-elles liées à leurs activités politiques précédentes et elles constituèrent une sorte de revanche de la part du roi pour l'avoir porté sur le trône de Pologne. 